\title{
E-Government Based Urban Governance on the Smart City Program in Makassar, Indonesia
}

\author{
Rudi Hardi $^{1 *}$, Srirath Gohwong ${ }^{2}$ \\ ${ }^{1}$ Department of Government Studies, Faculty of Social and Political Sciences, Universitas \\ Muhammadiyah Makassar, Jl. Sultan Alauddin No.259, Makassar, 90221, Indonesia. \\ ${ }^{2}$ Department of Political Science and Public Administration, Faculty of Social Sciences, \\ Kasetsart University, No. 50 Ngamwongwan Road, Lat Yao Subdistrict, Chatuchak District, \\ Bangkok, 10900, Thailand.
}

Received: 2020-03-13; Accepted: 2020-04-27; Published: 2020-04-30

\begin{abstract}
This article discusses about urban governance of Smart City Program in the Makassar City, which is the mainstay program of the Makassar City Government and identifies factors that are driving and inhibiting the realization of Good Urban Governance based on E-Government in Smart City Program. This type of research was qualitative with a descriptive approach. Data collecting was used instrument in the form of observation and documentation then developed from the interviews of informants. The fact in the field indicated that $E$ Government-based urban governance on Smart City program in the Makassar is seen from the indicators of urban management, namely planning, organizing, implementing and controlling according to the development goals in the Makassar Government's vision and mission.
\end{abstract}

Keywords: Urban Governance; E-Government; Smart City

How to Cite: Hardi, R., \& Gohwong, S. (2020). E-Government Based Urban Governance on the Smart City Program in Makassar, Indonesia. Journal of Contemporary Governance and Public Policy, 1(1), 12-17.

Permalink/DOI: https://doi.org/10.46507/jcgpp.v1i1.10 


\section{Introduction}

Recently, the era of industrial revolution 4.0 where the government is required to realize good governance in all its main areas of public service. The realization of good governance as an illustration of the latest governance is considered as the current achievement of the government in the middle of low public trust. Even the discourse of good governance has colonized public discourse in reform and democratization in Indonesia (Prianto, 2011).

This is in line with the effort to realize good governance in urban development in Indonesia. This effort is an inseparable part of the planning process that is increasingly developing in line with development of the establishment in general. These developments are characterized by the transformation of the capability of science and technology fields which are accompanied by pressures due to socio-economic transformation that occur and have a major influence on urban development (Nurmandi, 1999).

The Regional Medium-Term Development Planning through the Makassar Regional Regulation Number 5 of 2014 contains the Vision of the Makassar Government outlined in three missions namely reconstructing the people's destiny, restoring urban spatial planning, and reforming governance into corruption-free world-class public services. The leadership period of Danny Pomanto and Syamsul Rizal raised the Vision of the Makassar of the World which is convenient for all people.

The transformation of bureaucracy is a necessity. One way of bureaucratic transformation in public service is the application of information and communication technology (ICT) in public service (Supardal, 2016). So to achieve it, the Smart City Concept is used in order to realize that Makassar has the nuances of the City of the World. Makassar City is on a trade, social, economic, political, educational and technological path in Eastern Indonesia that has the potential to realize Smart City effectively because the strategic location requires people to get to know technology quickly.

To develop and realize a smart city in the Makassar, it is not merely pegging and making IT and technology solutions as the ultimate goal but more focused on innovation and breakthroughs to solve priority problem and develop regional leading sector. Smart city development does not merely prioritize efficiency and bureaucracy by utilizing information and communication technology (ICT) but also builds the community by making ICT infrastructure and facilities as supporting factor or enabler.

\section{Research Methods}

This research was used the qualitative with descriptive approach that attempted to describe in detail about the problems to be studied which are obtained directly in the field according to the circumstances of the object under study. The study conducted on August, 5 - October 5 2019. The study was conducted in Makassar City with the location of the study carried out at the Makassar City Communication and Information Office, Makassar City Spatial Planning and the Regional Development Planning Agency of Makassar City with the consideration of having important role in urban development by implementing information and communication technology development in implementing smart city program. 


\section{Result and Discussion}

Indeed, the implementation and support from the government for the development of e-government in Indonesia began to appear in the period of the early 1990s. Although the institutions that were competent for the development of information system in public organization was actually existed in the previous decades (Mustapa, 2011). Even so, the discussion about smart city at that time as part of the implementation of e-government is still rarely being a discussion and implementation by local and central government.

In this sophisticated and transparency era, the use of information and communication technology in government and public institution is a necessity that cannot be negotiated because information technology is proven to be able to improve service quality that is more responsive, effective, efficient and accountable (Sitokdana, 2015). However, discussing the efforts to realize urban-based governance in the smart city program in Makassar certainly does not only require series of sophisticated technology systems. The realization of good urban governance will never be separated from the principles of good management, that are, the need for good planning, good organization, the implementation that is in line with expectation and structured and massive control.

In good planning, it is necessary to formulate a work plan that is in accordance with clear goal and objectives. In the Makassar Government, it can be concluded that each Regional Work Unit (SKPD) has good planning products in each SKPD which are represented in the form of regional regulations and other planning documents that will determine the range of activities to achieve the desired results to suit with the hope of the Makassar Government in implementing the smart city program.

Forming a smart city is not easy. It is need good smart plan, smart partner (productive work partner) and good community support that can be an encouragement for the formation of creative program (smart people) (Fathun, 2016). Smart city is a work plan for each Makassar City SKPD, the strategic plan of smart city programs in Makassar City that want to be achieved include Optimizing the use of information technology, postal and telecommunication development program, information and communication system development program. Besides, putting vision and government implementation mission, city infrastructure, environment, finance, and smart city based.

Similarly, the organization of urban management is intended to classify the activities needed and how the relationships between these activities in a form of organizational or institutional structure. Although currently the institutional model in managing the application of information and communication technology in the Makassar City Government has not yet created an integrated system with each other and there is no one unit that is directly responsible to the Mayor who has the same level of authority as the related agency or institution (Amri, 2017).The dominant institution in city and regional governance is a government organization. The organizing was carried out by the Makassar City Government by issuing a Decree on the Establishment of Sombere 'and Smart City Technical Implementation Teams. Related to the relationship between the technical implementation team that continue to coordinate directly and 
indirectly in order to be able to realize quality public services based on information and communication technology in the context of implementing smart city in Makassar City. The good quality public services are very basic demands in a good governance system (Muhammadiah, 2011).

After the organization is formed, human resources are needed to move.So that, it is need to do stuffing, which is filling the appropriate person to carry out the tasks and function of the part of the organization. The program implementation that want to realize Makassar as Smart City requires a work program. Therefore, each Regional Work Unit (SKPD) must have its own work program so that the work or activities carried out go according to plan and can achieve the objectives. For example the Bappeda work program, namely the Development Planning Information System Regional (SIPPD) and Management Monitoring and Evaluation Information System (Monev SIM), work program of the Office of Spatial Planning and Building, namely Spatial Information Services Website, and work program of the Office of Communication and Information, namely the provision of an online open data database service. In addition, Makassar has been able to monitor traffic congestion and the online parking payment system that is already on the track. In addition, Makassar also has Makasar Smart Card which can be used for prominence matters of government system and payment (Insani, 2017).

A well-structured implementation will never be separated from the control in accordance with the norms of the program. Control activities are include the internal control of organization and external organization or activities that occur in the community. Organizational internal control is carried out in accordance with the existing organizational culture. The purpose of organizational control is for the implementation of the duties and functions of each organizational component according to the plans and programs that have been set. Based on the results of the interview above, the researcher can concluded that the control in the implementation of the Makassar smart city program is carried out by each SKPD head in the form of reporting, monitoring and others will then be followed up by the Mayor of Makassar to evaluate what is not in accordance with previous planning so if there is a deviation, it can be known and can be followed up.

This control can ensure that the existence of strict supervision of the implementation of the Smart City program gives hope to the community of negative perceptions wide spread recently. Bureaucracy in carrying out government and development tasks including the implementation of public services is given the impression that there is a long and convoluted process if the community completes its affairs related to the service of government apparatus (Usman, 2011).

\section{Conclusion}

E-Government Based Urban Governance on the Smart City Program was seen from good management indicators. In Makassar, the urban management can be seen in the presence of each Regional Work Unit (SKPD) which has its own planning products in the form of regional regulations and other planning documents to meet the expectation of the Makassar Government in implementing smart city programs. Second, the organizing 
carried out by the Makassar Government through issuing a Decree on the Establishment of Sombere 'and Smart City Technical Implementation Team. Third, the coordination is carried out both directly and indirectly. The implementation of Makassar as a Smart City requires a work program so that each Regional Work Unit (SKPD) must have a separate work program to run according to plan in order can achieve the objectives. Lastly, the control of the implementation of the Makassar smart city program was carried out by each SKPD head in the form of reporting, monitoring and others then will be followed up again by the Mayor of Makassar.

\section{Acknowledgments}

This work was supported by Department of Government Studies, Faculty of Social and Political Sciences, Universitas Muhammadiyah Makassar, Indonesia in cooperation with Political Sciences Association of Kasetsart University (PSAKU).

\section{References}

Amri, A. (2017). Analisis pemanfaatan teknologi informasi dan komunikasi dalam menunjang terwujudnya Makassar sebagai "smart city." KAREBA: Jurnal Ilmu Komunikasi, 5(2), 431445.

Fathun, L. M. (2016). Paradiplomasi Menuju Kota Dunia: Studi Kasus Pemerintah Kota Makassar. Indonesian Perspective, 1(1), 75-94.

Insani, P. A. (2017). Mewujudkan Kota Responsif Melalui Smart City. Publisia: Jurnal Ilmu Administrasi Publik, 2(1). https://doi.org/10.26905/pjia p.v2i1.1423

Muhammadiah, M. (2011). Reformasi Pelayanan Publik Sebagai Strategi Mewujudkan Good
Governance. Otoritas: Jurnal Ilmu Pemerintahan, 1(2). https://doi.org/10.26618/ojip .v1i2.27

Mustapa, Z. (2011). Reformasi Birokrasi Melalui EGovernance: Peluang atau Tantangan Dalam Pelayanan Publik? Otoritas : Jurnal Ilmu Pemerintahan, 1(2). https://doi.org/10.26618/ojip .v1i2.29

Nurmandi, A. (1999). Manajemen perkotaan: aktor, organisasi, dan pengelolaan daerah perkotaan di Indonesia. Yogyakarta: Lingkaran Bangsa.

Prianto, A. L. (2011). Good Governance dan Formasi Kebijakan Publik Neo-Liberal. Otoritas: Jurnal Ilmu Pemerintahan, 1(1). https://doi.org/10.26618/ojip .v1i1.11

Sitokdana, M. N. N. (2015). Evaluasi Implementasi eGovernment Pada Situs Web Pemerintah Kota Surabaya, Medan, Banjarmasin, Makassar dan Jayapura. Jurnal Buana Informatika, 6(4). https://doi.org/10.24002/jbi. v6i4.461

Supardal, S. (2016). Penerapan ICT dalam Pelayanan Publik di Kabupaten Bantul. Otoritas: Jurnal Ilmu Pemerintahan, 6(2), 120. https://doi.org/10.26618/ojip .v6i2.272

Usman, J. (2011). Manajemen Birokrasi Profesional Dalam Meningkatkan Pelayanan Publik. Otoritas: Jurnal Ilmu Pemerintahan, 1(2). https://doi.org/10.26618/ojip .v1i2.24 
(C) 2020 by Autors. Submitted for possible open access publication under the terms and conditions of the Creative Commons Attribution (CC BY SA) license (https://creativecommons.org/licenses/by-sa/3.0/). 